i forhold til egen krop og begær. Tanken er inspirerende, men hvem er bare lidt mere præcist 'alle andre moderne kvinder', der i mellemkrigstiden har levet på kvindeligheden som spærret psykisk struktur? Er klassemæssige differentieringer ikke længere relevante? Eller har almengørelsen en mere principiel rod: at den psykosemiotiske tilgang nok gør det muligt at grave særdeles dybt $i$ et forfatterskabs ubearbejdede psykiske lag, men samtidig gør det vanskeligt at fastholde en stoflig historisk optik?

Lise Busk-Jensen

\section{Formløshedens sponta-} ne nærvær

\section{Merete Stistrup Jensen, Bente Liebst og Karen Klit- gaard Povlsen: Hjertets Bre- ve, Aalborg Universitetsfor- lag 1988.}

\section{Lotte Thrane: Romanen der revnede, Museum Tuscula- num, København 1989.}

Engang i 1970'erne formede den tyske feminist og litteraturforsker Silvia Bovenschen begrebet om kvindernes 'før-astetiske rum.' Hun forstod herved den kvindelige virksomhed, der er mere end det blot funktionelle hus- arbejde, men mindre end det fuldt objektiverede æstetiske værk skabt til at cirkulere $i$ offentligheden. Kvinder har måttet dyrke deres astetiske talenter inden for husarbejdets og hjemmets rammer. Intimsfærens rumlige adskillelse fra offentligheden har bestemt form og indhold i deres arbejdsmåde. Når det er lykkedes kvinderne at trænge ud i kunstens sfære, er det altid sket via de tilgrænsende f $\varnothing$ r-æstetiske rum, mente Bovenschen. F.eks. trængte kvinderne i 1700 -tallet ud $\mathbf{i}$ den litterære offentlighed via deres færdighed i brevskrivning, hvorfra springet til brevromanen ikke var stort.

Bovenschen havde fået kig på nogle fremtrædende romantikeres store brevproduktion. Kvinder som Caroline Schlegel, Rachel Varnhagen og Bettina von Arnim havde været en integreret del af det $h \varnothing j t$ estimerede tyske romantikmiljø, men fordi de havde holdt sig inden for brevgenrens før-æstetiske rum, havde de også vanskeligt ved at holde deres placering i litteraturhistorien. Hvis kvindeforskningen skulle kunne beskæftige sig med disse forfatterinder uden for biografiens rammer, måtte man begynde at læse deres breve som litterære tekster og udvide begrebet 'forfatterskab' til at omfatte hele deres virksomhed i de før-æstetiske rum. Denne tankegang var meget karakteristisk for den tidlige visionære kvindeforskning, der satsede på radikale ændringer i videnskabens teoretiske systemer, således at et nyt kulturelt landskab, der også omfattede kvinderne, kunne komme til syne.

Silvia Bovenschens teorier blev 
hurtigt introduceret i Danmark af Jette Lundbo Levy. De centrale afsnit fra artiklen "Über die Frage: gibt es eine weibliche Ästhetik? « blev oversat i Hug! 14, 1977. Senere fulgte Tania $\emptyset$ rum problemstillingen op i Pamelas døtre (1985), hvor Richardsons Pamela blev læst som et eksempel på en oprindelig kvindelig genres emancipation, brevet der er vokset ud af intimsfæren og endt som grundformen for 1800 -tallets dominerende prosagenre: romanen. Brevet kunne nu læses som en (før)æstetisk tekst og som en særlig kvindelig genre, og kvindeligheden kunne findes som et underliggende mønster $i$ en af litteraturens ellers så mandsdominerede hovedgenrer.

Det paradigme, der her var opridset, mellem kvinderne, brevet og litteraturen, har virket uhyre tillokkende for kvindeforskerne. Her var udkastet til et typisk kvindeforskningsprojekt: et nyt stort materiale at hente frem, nye forfatterskaber at karakterisere og en ny synsvinkel på den velkendte romanlitteratur; måske i sidste ende etableringen af nye æstetiske teorier omkring brevet som en grundform. Og nu har Merete Stistrup, Bente Liebst og Karen Klitgaard Povlsen, der for en tid var kolleger på Aalborg universitetscenter, gjort forsøget på at skrive disse kvindebreves historie i Hjents Breve. I forordet knytter de an til de skitserede tankegange om sammenhængen mellem brevformen og kvindelivet, om brevet som en litterær forform og særlig kvindelig genre, og herefter følger 17 kapitler, der dels præsenterer franske, tyske og danske brevskrivende kvinder fra perioden 1650-1930, dels tegner et billede af kvindelighedens udvikling i perioden.

Problemet for kvindeforskningen efter 70 'ernes store projektudkasttid er, at de nye beregner nok skabte et nyt materiale, men at dette materiale ikke nødvendigvis var helt ukendt eller uberørt af den før-feministiske forskning. Det gælder således for alle de forfatterinder, som Hjertets Breve behandler, at de er højst velkendte $\mathrm{i}$ litteraturhistorien; Mme de Sévigné, Germaine de Staël, Caroline Schlegel, Bettina von Arnim, Kamma Rabek, George Sand, Karin Michaëlis og Colette er navne, hvorom der allerede findes en stor sekundærlitteratur, der belyser deres liv og værker biografisk og kulturhistorisk. Stistrup, Liebst og Klitgaard Povlsen har valgt at gå uden om denne sekundærlitteratur for at skrive direkte fra den ny feministiske position. Det betyder, at selv danske varker som Elisabeth Hudes store Caroline Schlegel-monografi, Brandes' essay om Kamma Rabek og Bobés mange b $\not \varnothing-$ ger om Frederikke Brun og Bakkehuset ikke figurerer, hverken på litteraturlisterne eller i teksten.

$\mathrm{Nu}$ kan man måske sige, at et så stort projekt nødvendiggør, at man går frisk til sagen. Hjertets Breve er da også båret af en udpræget lyst til at fortælle, diskutere og skaffe overblik. Stoffet er samlet ind med forudsætningsløshedens begejstring. Forfatternes fremstillingsmetode har været, skriver de i forordet, at »lade læseren folge nogenlunde de samme veje som vi har gjort.« Imidlertid ser vi læsere alt for sjældent det primærmateriale, 


\section{$K \& K$ ANMELDELSER}

som tolkningerne bygger på. "Det er i dag næsten pinagtig at læse Carolines breve til Schelling og $\mathrm{i}$ dem fornemme den totale underkastelse«, hedder det, men et eksempel på disse pinagtigheder præsenteres vi ikke for. Derfor er kapitlerne om opdragelsesskrifterne (Rousseau, Ewald og Mme de Saussures) og Kamma Rabek egentlig de mest tilfredsstillende, fordi her ikke bygges st $\emptyset$ rre tolkninger op, end det empiriske materiale kan bære.

På trods af sekundærlitteraturens usynlighed fortæller forfatterne alligvel, paradoksalt nok, at de på grund af stoffets omfang har måttet "sæette sig på skulderene af andre [...] undertiden endda som ravne, for ikke at sige som eftersnakkende papegøjer“ (forordet). Det ses faktisk i teksten, når de har overtaget andres bevidstløse karakteristikker og f.eks. kan skrive om Mme Récamier, at hun havde en "fin og skarp intelligens" (s.91), men især også når det virker som om, de aldrig har haft grundteksterne $\mathrm{i}$ hånden. Hverken de Staëls Corinne eller Sands Lélia er brevromaner, som det hævdes; det kan man forvisse sig om blot ved at betragte skriftbilledet.

Især Karen Klitgaard Povlsen forsøger i sine kapitler om »Salonkultur og brevlitteratur « og »Brevet og æstetikteorierne« at få styr på den teori, der kunne holde sammen på materialet og lette fordøjelsen. Meget klart formuleres det centrale spørgsmål s. 33: „Er brevene en blot og bar kommunikationsform eller er de også, eller snarere en litterær genre? « Men få sider længere fremme svarer hun selv opgivende: »Det er derfor [...] svært nøjagtig at definere hvilke breve, der er private og hvilke, der er kunst-breve. Og det er heller ikke så vigtig. Vigtigt er det derimod, at der bliver skrevet mange breve af kvinder«(s.37-8). Jeg tror, at årsagen til den manglende teoretiske afklaring er, at der analyseres ud fra for mange parametre (uborgerlig-borgerlig, kvinde-mand; oprør-undertrykkelse, naturkultur, aktiv-passiv, jeg-ikke-jeg, formkaos, proces-resultat m.fl.), og at grundmaterialet: brevet, dagbogen, brevromanen ikke defineres tilstrækkelig grundigt. På en måde bliver bogen således kongenial med sit materiale, hvorom det bl.a. hedder, at kvindernes breve var »udtryk for en spontan formløshedens nærvær« (s. 152).

Lotte Thranes bog om Elisabeth Hansens roman Dido og Don Pedro fra 1821, Romanen der revnede, samler sig helt modsat Hjertes Breve om en enkelt tekst og et lille forfatterskab, der før feminismens dage var så ukendt, at selv Vilh. Andersen ikke har fået det med i sin litteraturhistorie. I 1980 præsenterede Vibeke Blaksteen Elisabeth Hansen i en artikel i $E d d a$, hun er akkurat næevnt i Stig Dalager og Anne-Marie Mais Danske Kvindelige forfattere (1982) og blev litteraturhistorisk placeret af MarieLouise Svane i Dansk litteraturhistorie bd.V (1984).

Thrane læser romanen på tre niveauer: som en didaktisk 1700-tals roman, der skal modstille det gode og det onde og vinde læseren for det gode; som en dannelsesroman i 1800 - 


\section{$K \& K$ ANMELDELSER}

tallets stil, der skal følge en menneskelig udviklingsproces; og som en kærlighedsroman. På alle de tre niveauer finder Lotte Thrane, at romanen revner; opdragelsen til den 'gode' kvindelighed betyder personlighedens død; dannelsesmønsteret kunne ikke omfatte kvinder, som ikke måtte gøre erfaringer i samfundslivet, og netop disse erfaringers internalisering er værdien $i$ det mandlige dannelsesforløb; og kvinderne med de bitre kærlighedserfaringer erobrer scenen fra den dydige heltinde. Disse analyser ưvikles så omhyggeligt, at teksten selv (som jeg ikke har læst) kan have en tendens til at glide $\mathbf{i}$ baggrunden. Man glemmer næsten, at »Romanens patetiske hovedudsagn og pessimismen kan gøre den svær at sluge i dag«, at »Hovedpersonerne er [...] skabelonagtige, intrigen usandsynlig og handlingen overlæsset«, at "forfatteren ikke er nogen stor stilist, men skamløs genbruger af udtryk som »kærlighedens almagt «, »skingrende latter« og »hvide barm《«, som Thrane selv karakteriserer sin tekst. Udover tekstanalysen rummer bogen en fin gennemgang af kilderne til Elisabeth Hansens liv og litterære arbejde. 